\title{
Effects of aminoguanidine treatment on endothelial nitric oxide synthase expression and nitric oxide levels in streptozotocin induced diabetic rats
}

\author{
Ilker Parmaksiz ${ }^{1 *}$, Onder Sirikci ${ }^{2}$, Serpil Bilsel ${ }^{2}$, Humeyra Turan Akdeniz ${ }^{2}$, Dilek Gogas Yavuz ${ }^{3}$
}

\begin{abstract}
Objective: Formation of advanced glycation end products (AGE) in Diabetes Mellitus contribute to endothelial dysfunction by permanent modifications of proteins and decrease NO concentration which regulate vascular tonicity and thus endothelial functions. We investigated the effects of AGE inhibitor aminoguanidine (AG) treatment on endothelial nitric oxide synthase (eNOS) expression and NO levels in Streptozotocin induced diabetic rats.
\end{abstract}

Material and methods: 38 male Sprague-Dawley rats were separated into 4 groups. Group $1(\mathrm{n}=9)$ was control group without any intervention (C group). Group $2(\mathrm{n}=10)$ received $\mathrm{AG}$ in drinking water ( $\mathrm{C}+\mathrm{AG}$ group). Third $(\mathrm{n}=10)$ and fourth $(\mathrm{n}=9)$ groups received $65 \mathrm{mg} / \mathrm{kg}$ Streptozotocin intraperitoneally to induce diabetes. Group 3 was followed without further intervention (DM group). Group 4 received aminoguanidine in drinking water (DM+AG group). After 12 weeks, serum NO levels were determined with chemiluminescence and eNOS expressions in heart and kidney tissues were determined with Western-Blot together with blood glucose and HbA1c levels.

Results: Serum NO levels were significantly lower in $\mathrm{DM}(\mathrm{P}<0.001)$ and $\mathrm{C}+\mathrm{AG}(\mathrm{P}<0.0005)$ groups compared to $\mathrm{C}$ group. There was no significant difference between the NO levels of DM and DM+AG groups. eNOS protein levels in heart tissues were significantly lower in DM group $(\mathrm{P}<0.05)$ than the $\mathrm{C}$ group. eNOS levels were significantly higher in $\mathrm{DM}+\mathrm{AG}(\mathrm{P}<0.01)$ than $\mathrm{DM}$ group. There was no significant difference in eNOS levels in kidney tissues among the groups. The results were compared with Mann-Whitney U test.

Conclusion: Decreased NO levels in DM group were consistent with the literature. eNOS expression in heart tissues were decreased in DM group, their concentration were increased with AG therapy. Further studies are needed to elaborate the effects of AG in tissues and the side effects observed in some studies.

Key words: Diabetes Mellitus, Streptozotocin, Aminoguanidine, Nitric Oxide

\section{Introduction}

Micro and macrovascular complications are a prominent cause of morbidity and mortality in diabetic patients. Endothelial cells have an important role in the maintenance of vascular tonus, platelet aggregation and secretion of vasoactive substances, and endothelial dysfunction is one of the disorders that can be observed, starting from very early stages in diabetes. Disturbances in nitric oxide (NO) synthesis from L-arginine by the activity of endothelial nitric oxide synthase (eNOS) in endothelial cells have been implied and investigated in the endothelial dysfunction observed in vascular complications of diabetes. Apart from being a very potent vasodilator,
NO has anti atherogenic properties by decreasing thrombocyte and leukocyte adhesion to endothelium and inhibiting smooth muscle cell proliferation (1). There are various articles which state that endothelial vasodilatation mediated by NO is increased, decreased or unchanged in insulin dependent diabetes models (2). Also, formation of advanced glycation end products (AGE) has been suggested to be related with endothelial dysfunction in diabetes (3). Aminoguanidine, which inhibits the formation of AGE has been suggested to increase vasodilatation and slow down the formation of diabetic nephropathy (4).

Received 28-02-2016 Accepted 01-04-2016 Available Online 15-05-2016

1 Sehitkamil State Hospital, Department of Biochemistry, Gaziantep, Turkey

2 Marmara University Medical Faculty, Department of Biochemistry, Istanbul, Turkey

3 Marmara University Medical Faculty, Department of Internal Medicine, Endocrinology and Metabolism Unit, İstanbul, Turkey

* Corresponding Author: Ilker Parmaksiz E-mail: ilkerp76@yahoo.com Phone: +90 3423246767 
We aimed to investigate the changes in NO levels and the expression of NOS in heart and kidney tissues in a streptozotocin induced diabetes rat model and examine the effects of aminoguanidine on serum $\mathrm{NO}$ levels and the expression of tissue NOS isoenzymes.

\section{Materials and methods}

38 ten week old male Sprague-Dawley rats were included, which were divided to 4 groups and were fed with standard diet containing $20 \%$ protein. Group $1(n=9)$ was followed as control group without any intervention (C group). Group $2(\mathrm{n}=10)$ received 1 $\mathrm{g} / \mathrm{L} /$ day aminoguanidine (ICN Biomedicals Ohio, USA) in drinking water ( $\mathrm{C}+\mathrm{AG}$ group). In order to induce diabetes, third and fourth groups received a 65 $\mathrm{mg} / \mathrm{kg}$ single dose of streptozotocin (STZ) (Sigma, St. Louis MO, USA) intraperitoneally (5). Rats with a blood glucose level above $200 \mathrm{mg} / \mathrm{dl}$ in a blood sample taken a week later from the caudal vein were regarded as diabetic. Group $3(n=10)$ were followed without any further intervention (DM group). Group 4 $(\mathrm{n}=9)$ received $1 \mathrm{~g} / \mathrm{L} /$ day aminoguanidine in drinking water (DM+AG group). 12 weeks after the induction of diabetes, the animals were sacrificed by bleeding under ether anesthesia to take intra-cardiac blood and tissue samples from heart and kidneys. Animal experiments were carried in the experimental animal research laboratory of Marmara University School of Medicine. All experiments and handling of animals complied with National Institute of Health Guide for the care and use of Laboratory Animals and were approved by the ethical committee of Marmara University for experimental animals.

Serum glucose levels were determined spectrophotometrically (Modular P800, Roche Diagnostics, Germany) (6). Plasma HbA1c levels were determined using ClinRep Complete Kit (Recipe, Germany) with reverse phase HPLC (Spectra, Thermo Electron Corporation, USA) with UV 1000 Detector at $415 \mathrm{~nm}$ (7). Serum NO levels were determined by the detection of photons (based on the principle of conversion of nitrate to $\mathrm{NO}$ by vanadium (III) chloride and NO to NO2 after reacting with ozone in a closed environment, and the emission of photons as excited NO2 returns to their ground state) with chemiluminescence with (NO analyser Sievers 280i, USA)(8, 9).

The heart and kidney tissue samples were homogenized (IKA, Ultra Turrax T25, Germany), centrifuged and the supernatant was used to detect the expressed isoforms of NOS (10). Homogenates containing $70 \mu \mathrm{g}$ protein for heart, and $100 \mu \mathrm{g}$ for kidney were denatured at $95^{\circ} \mathrm{C}$ in loading buffer (11) and the isoforms were separated with SDS-PAGE (Bio-Rad Protean II xi, USA), together with Rat Brain Extract (Santa Cruz Biotechnology, USA) for positive control and Protein Marker III (Applichem, Germany) as molecular weight marker. The separated isoforms were transferred to nitrocellulose membrane (BioRad Transblot cell, USA) and immunoblotted with antibodies against eNOS and Glyceraldehyde-3Phosphate Dehydrogenase (GAPDH) as housekeeping protein (Santa Cruz Biotechnology, USA) (12). Bound antibodies were visualized with amplified horseradish peroxidase bound secondary antibodies (BioRad, USA) and band intensities were digitized (Vilber Lourmat, Germany) in TIFF format and pixel intensities of bands were counted in equal size areas with ImageJ software and expressed as pixel intensity/ug protein (13). The ratios of eNOS protein expression to the expression of housekeeping protein GAPDH were calculated, the ratio of eNOS/GAPDAH of $\mathrm{C}$ group was accepted as 1 and the other groups' ratios were calculated and expressed as multiples of 1 .

Statistical comparisons of the data were done with non-parametric Mann Whitney $U$ test (GraphPad InStat Version 3.05). The differences between groups were considered significant when $\mathrm{P}<0.05$ with $95 \%$ confidence interval.

\section{Results}

The blood glucose level of DM and DM+AG group were significantly increased compared to the $\mathrm{C}$ group $(\mathrm{P}<0.0001$ and $\mathrm{P}<0.01$, respectively). The glucose levels of $\mathrm{DM}+\mathrm{AG}$ group was also higher than $\mathrm{C}+\mathrm{AG}$ group's $(\mathrm{P}<0.03)$.

The HbA1c levels of DM $(\mathrm{P}<0.0001)$ and $\mathrm{DM}+\mathrm{AG}$ groups $(\mathrm{P}<0.001)$ were statistically higher than the $\mathrm{C}$ group. There was no significant difference between $\mathrm{DM}$ and $\mathrm{DM}+\mathrm{AG}$ groups.

The NO levels of DM and DM+AG groups were significantly decreased compared to $\mathrm{C}$ group ( $\mathrm{P}<0.001$, and $\mathrm{P}<0.0005$, respectively). There was no difference between the NO levels of DM and $\mathrm{DM}+\mathrm{AG}$ groups, however, $\mathrm{C}+\mathrm{AG}$ group also had significantly decreased NO levels compared to $\mathrm{C}$ group $(\mathrm{P}<0.0005)$. The results of glucose, HbAlc and NO levels are presented in Table 1.

In the heart tissue, the expression of eNOS was significantly decreased in DM group compared to $\mathrm{C}$ $(\mathrm{P}<0.05)$ and $\mathrm{DM}+\mathrm{AG} \quad(\mathrm{P}<0.01)$. The eNOS expressions of $\mathrm{C}, \mathrm{C}+\mathrm{AG}$, and $\mathrm{DM}+\mathrm{AG}$ groups were not different. When the expression of eNOS was compared in kidney tissue, there was no difference among groups (Table 2).

The eNOS/GAPDH pixel intensity ratio was significantly decreased in the heart tissues of DM group, when compared to $\mathrm{C}$ and $\mathrm{DM}+\mathrm{AG}(\mathrm{P}<0.005$ and $\mathrm{P}<0.01$, respectively). $\mathrm{C}, \mathrm{C}+\mathrm{AG}$, and $\mathrm{DM}+\mathrm{AG}$ groups were not different. When the eNOS/GAPDH pixel intensity ratio was compared in kidney tissue, there was no difference among groups. 
Table 1: Glucose, HbA1c and NO levels of groups presented as median (minimum - maximum)

\begin{tabular}{lcccc}
\hline & C & C+AG & DM & DM+AG \\
\hline Glucose; mg/dL & 174 & $155^{\#}$ & $533^{*}$ & $597^{* *}$ \\
& $(162-185)$ & $(142-174)$ & $(189-572)$ & $(310-751)$ \\
\hline \multirow{2}{*}{ HbA1c; (\%) } & 1.09 & $1.00^{\# \#}$ & $2.55^{*}$ & $2.01^{* * * *}$ \\
\hline \multirow{2}{*}{ NO; $\boldsymbol{\mu M}$} & $(0.71-1.50)$ & $(0.52-1.69)$ & $(1.54-3.94)$ & $(1.13-2.85)$ \\
\hline
\end{tabular}

* $\mathrm{P}<0.0001$ compared to $\mathrm{C},{ }^{* * *} \mathrm{P}<0.01$ compared to $\mathrm{C},{ }^{* * * *} \mathrm{P}<0.001$ compared to $\mathrm{C},{ }^{* * * *} \mathrm{P}<0.0005$ compared to $\mathrm{C}$, ${ }^{\#} \mathrm{P}<0.03$ compared to $\mathrm{DM}+\mathrm{AG},{ }^{\# \#} \mathrm{P}<0.0001$ compared to $\mathrm{DM}+\mathrm{AG}$,

Table 2: eNOS protein pixel intensities/ $\mu \mathrm{g}$ protein and eNOS/GAPDH ratios in heart and kidney tissues presented as median (minimum - maximum)

\begin{tabular}{|c|c|c|c|c|}
\hline & $\mathbf{C}$ & $\mathbf{C}+\mathbf{A G}$ & DM & $\mathbf{D M}+\mathbf{A G}$ \\
\hline $\begin{array}{l}\text { eNOS protein pixel intensities in } \\
\text { heart tissue (pixel/ } \mu \mathrm{g} \text { protein) }\end{array}$ & $\begin{array}{c}1.11 \\
(0.88-1.56)\end{array}$ & $\begin{array}{c}1.015 \\
(0.86-1.50)\end{array}$ & $\begin{array}{c}0.87^{*} \\
(0.73-1.30) \\
\end{array}$ & $\begin{array}{c}1.24^{\#} \\
(0.80-1.72)\end{array}$ \\
\hline eNOS/GAPDH ratio in heart & 1 & $\begin{array}{c}1.14 \\
(0.78-1.30)\end{array}$ & $\begin{array}{c}0.66^{* *} \\
(0.53-1.20)\end{array}$ & $\begin{array}{c}1.01^{\#} \\
(0.63-1.67)\end{array}$ \\
\hline 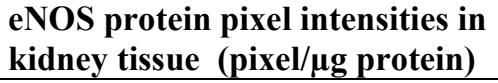 & $\begin{array}{c}0.78 \\
(0.63-1.05) \\
\end{array}$ & $\begin{array}{c}0.77 \\
(0.53-0.94) \\
\end{array}$ & $\begin{array}{c}0.81 \\
(0.66-0.99) \\
\end{array}$ & $\begin{array}{c}0.85 \\
(0.73-1.11) \\
\end{array}$ \\
\hline eNOS/GAPDH ratio in kidneys & 1 & $\begin{array}{c}1.13 \\
(0.65-2.00)\end{array}$ & $\begin{array}{c}0.98 \\
(0.76-1.58)\end{array}$ & $\begin{array}{c}1.08 \\
(0.87-1.18)\end{array}$ \\
\hline
\end{tabular}

* $\mathrm{P}<0.05$ compared to $\mathrm{C},{ }^{* *} \mathrm{P}<0.005$ compared to $\mathrm{C},{ }^{\#} \mathrm{P}<0.01$ compared to DM.

The eNOS expressions in heart and kidney tissues visualized with western blot are shown in Figure 1.

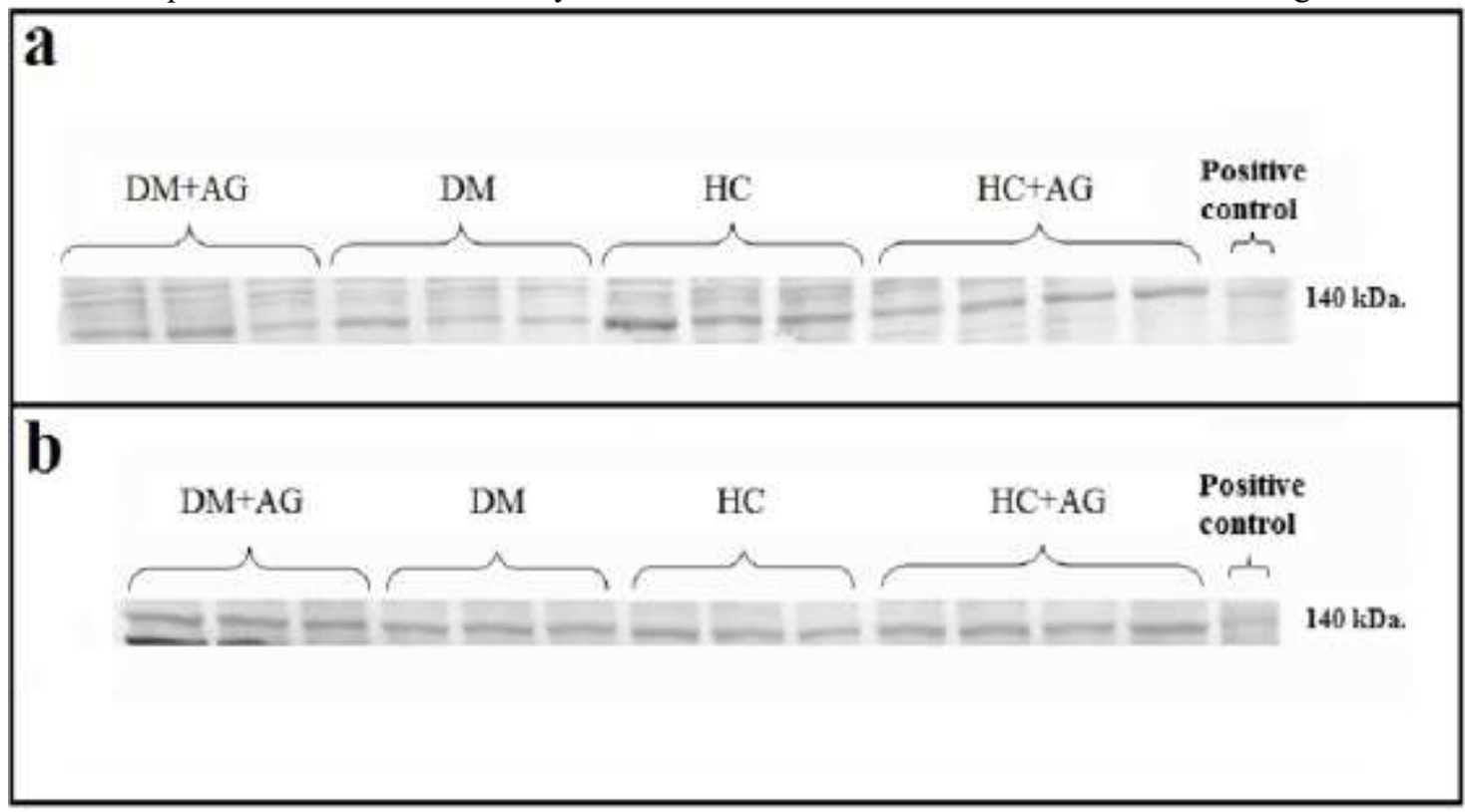

Figure 1: The representative western blots of (a) heart and (b) kidney tissue eNOS expression 


\section{Discussion}

Endothelial dysfunction is closely related with the micro and macrovascular complications of diabetes (14). Increased formation of AGE as a result of hyperglycaemia has been suggested as one of the mechanisms contributing to endothelial dysfunction (3). Advanced glycation is a relatively long process, taking weeks to form, and affect structural proteins with a long half-life (15). Therefore, in this study we chose to wait 12 weeks after the induction of diabetes before taking the samples to be analysed. It has been shown that inhibition of advanced glycation can decrease the rate of complications such as diabetic nephropathy, retinopathy and neuropathy (16). Aminoguanidine is a nucleophilic hydrazine molecule which was attempted to be used an anti-glycation agent.

We aimed to form a model of diabetes in rats with streptozotocin and after waiting for 12 weeks for the formation of AGE, we wanted to investigate how serum NO levels and tissue eNOS expression changes in this model and see if the effects of aminoguanidine are related to serum NO levels and eNOS expression.

The significant increase in glucose and HbAlc levels in $\mathrm{DM}$ and $\mathrm{DM}+\mathrm{AG}$ groups showed us that the induction of diabetes model was successful. HbAlc is the glycated form of haemoglobin and precedes AGE formation. Aminoguanidine interacts with dicarbonyl compounds derived from glucose to form 3-amino1,2,4-triazin molecules and thereby inhibit AGE formation. It does not have any effect on $\mathrm{HbAlc}$ but it has been suggested to compete with glucose for protein glycation in a dose dependent manner (17). Our finding that $\mathrm{HbAlc}$ was relatively less increased in $\mathrm{DM}+\mathrm{AG}$ group was compatible with this suggested. The fact that there was no difference in $\mathrm{C}$ and $\mathrm{C}+\mathrm{AG}$ groups $\mathrm{HbA1c}$ levels could be resulting from the fact that AGE formation was not increased in either groups or HbAlc not being elevated enough to cause any difference.

The NO levels were significantly decreased in DM and $\mathrm{DM}+\mathrm{AG}$ groups compared to $\mathrm{C}$ group, but were not different from each other. Also, $\mathrm{C}+\mathrm{AG}$ group had significantly lower NO levels compared to $\mathrm{C}$ group. Apart from other free radical species, $\mathrm{NO}$ has physiological functions in low concentrations. Smooth muscle relaxation, inhibition of platelet aggregation, anti-inflammatory and antioxidant effects and effects on kidneys and immune system are among the suggested functions. At the same time, some harmful properties such as consumption of antioxidants, inhibition of some enzymes, DNA damage and lipid peroxidation have also been attributed to NO. The differences in the various reports regarding the status of NO in insulin dependent diabetes models can be attributed to the duration and severity of diabetes, choice of tissue and vasodilator agent investigated.
The decrease we observed in $\mathrm{DM}$ and $\mathrm{DM}+\mathrm{AG}$ groups is in compliance with the reports that state NO mediated vasodilatation is impaired in diabetes (1820). The absence of any difference between DM and $\mathrm{DM}+\mathrm{AG}$ groups suggest that aminoguanidine does not show its effects through NO related mechanisms. Although not significant, the tendency to decrease in $\mathrm{DM}+\mathrm{AG}$ and $\mathrm{C}+\mathrm{AG}$ groups with respect to $\mathrm{DM}$ and $\mathrm{C}$ groups could also result from aminoguanidine having NOS inhibiting properties (17).

As in atherosclerosis, there are various and sometimes contradicting results about the expression and activity of eNOS in diabetic animal models. There are reports which state that the expression of eNOS from human aortic endothelial cells is decreased (21) or increased (22) under hyperglycaemia. Human glomerular endothelial cells exhibit increased expression of eNOS and decreased formation of NO under hyperglycaemic conditions (23). There are also other studies which report increased eNOS mRNA and protein (24)and contradictory decreased cGMP formation (25) in diabetic animals. Although research parameters such as the duration and type of diabetes, the tissue analyzed and the molecule investigated may vary, it is generally accepted that a change occur in NO related biological processes with the formation of diabetes (2). Our finding that the expression of eNOS was decreased in DM group in heart tissue was parallel to Srnivasan's findings which showed that long term exposure to high glucose concentrations decreased eNOS expression in endothelial cells (21). Another suggested mechanism is that an increase in transcription factors such as NF- $\square \mathrm{B}$ due to increased AGE (26) or AP-1 and reactive oxygen species due to hyperglycemia (21) inhibits the expression of eNOS. The observation that the same decrease was not observed in DM+AG group complies with the idea that aminoguanidine had succesfully inhibited the formation of AGE in this group. Aminoguanidine had no further effect on $\mathrm{C}$ group, probably because they already did not have an increased AGE production.

However, the observed effects in the heart tissue were not present in kidneys and no difference in eNOS expression was observed among groups. This might result both from the formation and effects of AGE may show variations among tissues and the different location and regulation of eNOS among different tissues.

\section{Conclusion}

Although we observed that eNOS expression was affected by aminoguanidine, clinical studies regarding the use of this drug in the prevention of diabetic complications were halted in the meantime due to potentially harmful side effects. More studies are required to understand aminoguanidine mechanism of action and characterization of its side effects. 
Conflict of Interest: The authors declare no potential conflicts of interest with respect to the research, authorship, and/or publication of this article.

Ethical issues: All Authors declare that Originality of research/article etc... and ethical approval of research, and responsibilities of research against local ethics commission are under the Authors responsibilities. The study was completed due to defined rules by the Local Ethics Commission guidelines and audits.

\section{References}

1. Kılınç A, Kılınç K. Nitrik oksit: Palme Yayıncılık, 2003.

2. Chatterjee A, Black SM, Catravas JD. Endothelial nitric oxide (NO) and its pathophysiologic regulation. Vascul Pharmacol. 2008;49(4-6):134-40.

3. Schalkwijk CG, Stehouwer CD. Vascular complications in diabetes mellitus: the role of endothelial dysfunction. Clin Sci (Lond). 2005;109(2):143-59.

4. Yavuz DG, Ersoz HO, Tuncel M, Sargon MF, Kucukkaya $\mathrm{B}$, Ahiskali R, et al. Effects of aminoguanidine on glomerular basement membrane thickness and anionic charge in a diabetic rat model. Int $\mathrm{J}$ Exp Diabetes Res. 2001;2(3):225-32.

5. Öntürk H, Özbek H. Deneysel diyabet oluşturulması ve kan şeker seviyesinin ölçülmesi. Genel tıp dergisi. 2007;17(4):231-6.

6. Trinder P. Determination of glucose in blood using glucose oxidase with an alternative oxygen acceptor. Ann Clin Biochem. 1969;6:24-7.

7. Recipe. Hemoglobin A1c (HbA1c) in Whole Blood (for Variant $^{\mathrm{TM}}$ and Modular HPLC Systems). 2012.

8. Kielbasa W, Fung HL. Nitrite inhalation in rats elevates tissue NOS III expression and alters tyrosine nitration and phosphorylation. Biochem Biophys Res Commun. 2000;275(2):335-42.

9. McMurtry MS, Kim DH, Dinh-Xuan T, Archer SL. Measurement of nitric oxide, nitrite and nitrate using a chemiluminescence assay:an update for the year 2000 Analusis. 2000;28(6):455-65.

10. Lowry OH, Rosebrough NJ, Farr AL, Randall RJ. Protein measurement with the Folin phenol reagent. J Biol Chem. 1951;193(1):265-75.

11. Tojo A, Kimoto M, Wilcox CS. Renal expression of constitutive NOS and DDAH: separate effects of salt intake and angiotensin. Kidney Int. 2000;58(5):2075-83.

12. BIO-RAD. Opti-4CN $\mathrm{N}^{\mathrm{TM}}$ Substrate Kit. Available from: http://www.bio-

$\mathrm{rad} . \mathrm{com} / \mathrm{webroot} / \mathrm{web} / \mathrm{pdf} / \mathrm{lsr} /$ literature/4100130.pdf

13. Stehouwer CD, Lambert J, Donker AJ, van Hinsbergh VW. Endothelial dysfunction and pathogenesis of diabetic angiopathy. Cardiovasc Res. 1997;34(1):55-68.
14. Tousoulis D, Papageorgiou N, Androulakis E, Siasos G, Latsios G, Tentolouris $\mathrm{K}$, et al. Diabetes mellitusassociated vascular impairment: novel circulating biomarkers and therapeutic approaches. J Am Coll Cardiol. 2013;62(8):667-76.

15. Singh VP, Bali A, Singh N, Jaggi AS. Advanced glycation end products and diabetic complications. Korean J Physiol Pharmacol. 2014;18(1):1-14.

16. Nenna A, Nappi F, Avtaar Singh SS, Sutherland FW, Di Domenico F, Chello M, et al. Pharmacologic Approaches Against Advanced Glycation End Products (AGEs) in Diabetic Cardiovascular Disease. Res Cardiovasc Med. 2015;4(2):e26949.

17. Thornalley PJ. Use of aminoguanidine (Pimagedine) to prevent the formation of advanced glycation endproducts. Arch Biochem Biophys. 2003;419(1):31-40.

18. Durante W, Sen AK, Sunahara FA. Impairment of endothelium-dependent relaxation in aortae from spontaneously diabetic rats. $\mathrm{Br} \mathrm{J}$ Pharmacol. 1988;94(2):463-8.

19. Johnstone MT, Creager SJ, Scales KM, Cusco JA, Lee BK, Creager MA. Impaired endothelium-dependent vasodilation in patients with insulin-dependent diabetes mellitus. Circulation. 1993;88(6):2510-6.

20. Williams SB, Cusco JA, Roddy MA, Johnstone MT, Creager MA. Impaired nitric oxide-mediated vasodilation in patients with non-insulin-dependent diabetes mellitus. J Am Coll Cardiol. 1996;27(3):567-74.

21. Srinivasan S, Hatley ME, Bolick DT, Palmer LA, Edelstein D, Brownlee M, et al. Hyperglycaemia-induced superoxide production decreases eNOS expression via AP-1 activation in aortic endothelial cells. Diabetologia. 2004;47(10):172734.

22. Cosentino F, Hishikawa K, Katusic ZS, Luscher TF. High glucose increases nitric oxide synthase expression and superoxide anion generation in human aortic endothelial cells. Circulation. 1997;96(1):25-8.

23. Takahashi T, Harris RC. Role of endothelial nitric oxide synthase in diabetic nephropathy: lessons from diabetic eNOS knockout mice. J Diabetes Res. 2014;2014:590541.

24. Pieper GM, Siebeneich W, Moore-Hilton G, Roza AM. Reversal by L-arginine of a dysfunctional arginine/nitric oxide pathway in the endothelium of the genetic diabetic BB rat. Diabetologia. 1997;40(8):910-5.

25. Lin KY, Ito A, Asagami T, Tsao PS, Adimoolam S, Kimoto M, et al. Impaired nitric oxide synthase pathway in diabetes mellitus: role of asymmetric dimethylarginine and dimethylarginine dimethylaminohydrolase. Circulation. 2002;106(8):987-92.

26. Goldin A, Beckman JA, Schmidt AM, Creager MA. Advanced glycation end products: sparking the development of diabetic vascular injury. Circulation. 2006;114(6):597-605.

Copyright (C) 2014 The Author(s); This is an open-access article distributed under the terms of the Creative Commons Attribution License (http://creativecommons.org/licenses/by/4.0), which permits unrestricted use, distribution, and reproduction in any medium, provided the original work is properly cited. All Rights reserved by international journal of Medical Science and Discovery. 